\title{
Good Governance Combination of Local Governance and E-Governance: A Conceptual Framework

\author{
Shyamala Diwakaran
}

\begin{abstract}
Our nation has the longest written constitution but the implementation of the Local Governance has been transferred and their efficiency has properly monitored or rectified by the state and central government. This is conceptual research has been done in the implementation process. This research mainly focused on quality of life. The Lack of Implementation process is connected with resource exploitation. Resource exploitation has two type's human resource exploitation and natural resource exploitation. The directly three systems are connected with sustainable development but overall development left without because of bureaucratic, social leaders, and Knowledgeable people this research is not critical research but this research has a starting point for many reformations. This concept has defined implementation process is not based on rule of law it should be considered by social issues and clearly instructing for the proper implementation process and reduce the level exploitation and monitoring the unethical professionals and their rectification processing time will be less. This concept has separated no proper implementation process and improper implementation and analyzing the important factors for the proper implementation process. The factors like misuse of power and inefficiency should not affect the proper implementation process. The result of the lack of implementation process is organized resource exploitation. This plan will reduce the worst handling of decentralization process may be a strong reason for the lack of implementation process will directly connect with the organized resource exploitation. This research focusing on the efficiency and equity of the governance strongly insisted people should train by the local governance free from favoritism, partial's and nepotism, thisplanhas look into transforming the local governance. It will solve prolonging and procrastination in their issues It will reduce the organized crime result of lack of implementation process. Identify the exploiter or victim. The idea will combine the education system Social system and governance syste into one roof. To analyze all type of social issues and protect the weaker section

Keywords: Local governance, organized resource Exploitation, Lack of Implementation, decentralization
\end{abstract}

\section{INTRODUCTION}

Nation cross $70^{\text {th }}$ Republic day each citizen is equal. There is no discrimination before the law and the governance system the implementation of our constitution has many controversies to the governance system. The right has to decide the resource of a personallocation of resource like a weaker section for women and children Beyond the limit it has caste creed and religion the constitution has to protect everyone but it has happens. Many villages does not attainurban growth.

Manuscript received on 30 March 2021 | Revised Manuscript received on 08 April 2021 | Manuscript Accepted on 15 October 2021 | Manuscript published on 30 October 2021.

* Correspondence Author

Dr. D. Shyamala*, Department of Management Studies, Chennai (Tamil Nadu), India.

(C) The Authors. Published by Lattice Science Publication (LSP). This is an open access article under the CC-BY-NC-ND license (http:///creativecommons.org/licenses/by-nc-nd/4.0/)
Need a quality of life and education for all Discrimination is a root cause of Exploitation. Our System has divided into three parts Governance system, social system, and Education system. These systems have responsibilities to implement our Indian constitution. The system has to decide the need and wants of a citizen. The issues have to travel by the implementation rules and judicial proceedings to find the solution. The local governance connects these 3 systems directly. Powerful governance to implementing the constitution is the Local governance

\section{LITERATURE REVIEW}

Mohd.et.al (2015) researched on Good governance and organizational performance in the public sector. The research was carried out among the public sector maintaining the leadership, stakeholder relationship, monitoring, accountability, risk management, and strategic management. The researchers used cross-sectional survey and variables by using person correlation the most factors of good governance that lead to public organizations performance will be analyzed based on Multiple Regression analysis. The researcher found the independent variables comprise good governance a public organization. They found conceptual framework highlight that organization performance achievement base on good governance a public organization

\section{RESEARCH OBJECTIVE}

Lack of implementation especially in Local governance

Comparative analysis of e-governance and Local governance

Cause these 4 types

1. Worst handling of a decentralization process

2. Materialistic force, Political force, Socialistic force and Unethical Professional Intellectual force

3. No Proper monitor and rectification process

4. High prolong and procrastination
Major types of issues studied by local governance
1. Personal issues
2. Public issues
3. Environment issues
4. Agricultural issues
5. Industrial issues

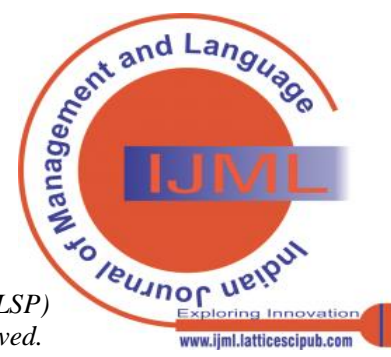




\section{CONCLUSION}

This social system has a concentration on the growth and development of the needy, not the exploiter. Now day's exploiter has the protective shield by these systems. The level has raised organized resource exploitation (including natural resource and human resource exploitation). Our Nation's father says the world is big enough to satisfy the needs of any person but too small to satisfy human greediness.Power Politics plays a vital role in solving the issues for all (or) a particular person is needy or exploiter

Organized crime has risen because of failure of the governance system; India is a traditional nation should not compare with the developed nation like Europe and USA. In our nation social system is training the people.Education system depends on the social system only. Discrimination is a root cause of exploitation now day's education is a brand and unethical professionals and their intellectual force are difficult to handle. Research idea the framework will reduce the social system of stress and measuring the performance of the local governance. It is concept or idea the entire process focused on good governance is the combination of local government social system and education system It has to be clear focusing on every issue and analyzing the needy and exploiter a people are trained by the social system, not by the governance but training has to be taken by the good governance focused on social secure measurements and overall social development not strengthening the particular people or caste This idea will reduce the level of exploitation and focusing the proper implementation process in all types of social issues. This transformation the local governance and instructing the powerful social systemstake part in it, to identify the needy and strengthen the weaker section. At Present we don't have a clear vision about issues based on geographical and demographically. Focus on the implementing authorities should free from socialistic force, political force, materialistic force and unethical professional intellectual force. There is a clear vision for transforming local governance into good governance. Each every citizen should train by the governance

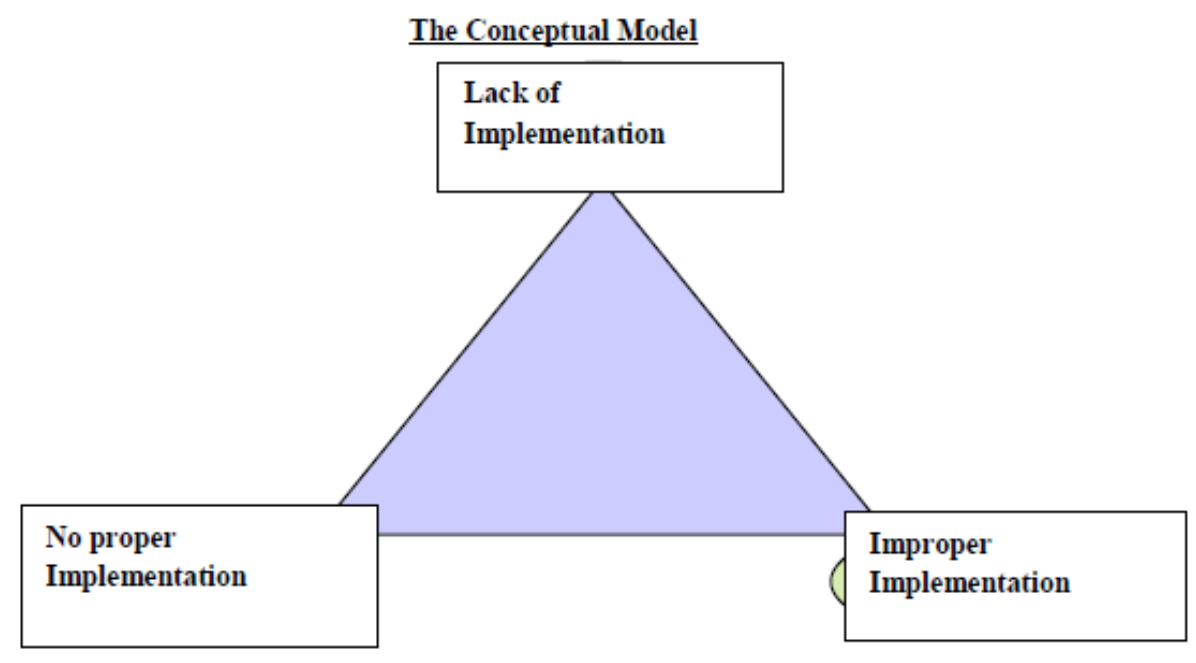

Coercive power has started to dominate by the exploiter. Organized crime result is organized resource exploitation highly non-communicable disease of three systems

The Person who already thinks about similar to this model The German Sociologist Max Weber argued that bureaucracy constitutes the most efficient and rational way in human activity can be planned and the logical process and organized hierarchies are necessary to maintain order, maximize efficiency and eliminate favoritism

Weber also described the bureaucratization of social order as "The polar night icy darkness" It will define human resource exploitation

The constitution of India is often taking part in a awfully necessary role within the context of Indian Society and Indian culture wherever many non secular area unit out there at wherever several languages, traditions thoughts, beliefs area unit out there India area unit communal Persons, laic person vis-à-vis Atheist additionally Specially, geographically position and condition of India is in international.

The constitution of India provides the correct to equality. As per Karl Max "By Equality, we must always perceive not that the degree of power of wealth be identical for everyone however that no national be rich enough to shop for another and none poor enough to be forced to sell him These statements were properly implemented by all these three systems. It is in paper and practical what are all difficulties to by bureaucrats for the proper implementation should be analyzed by this research.

\section{SCOPE OF STUDY}

This research is focused on the Lack of implementation processes and their outcomes In India three forms of governance are central, state and local governance. Implementing processes mostly covered by the local governance. Local governance is directly connected with the people. In a democratic nation, local governance should have a free hand in all issues to solve them in the right way. Protocol identity of government employees and Public representatives and identify the rights and allocating resources of a citizen. Fulfilling their livelihood and development of each every area in India should be treated equally. In Our constitution article 21 and subsection 26 focused on quality of life. Role-play should clearly be instructed by the local governance.

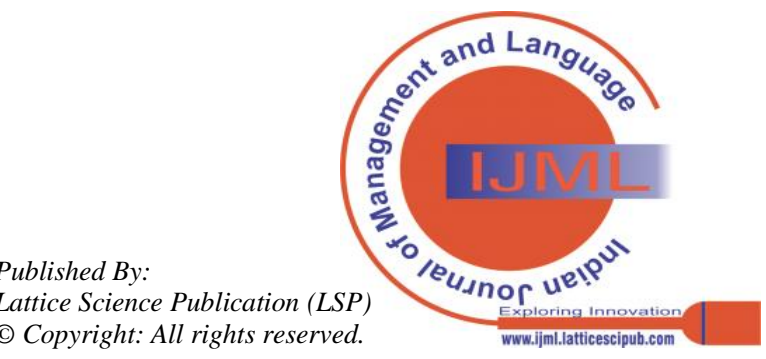


It will reduce due to misuse of power and inefficiency. Every citizen is equal according to our constitutional right to Equality must be given to all how far it has implementation especially in article $21 \mathrm{~A}$ and article 45 according to George Wilhelm Fred rich Hegel defines Education is the art of making man ethical. Weber analyzed one of these organizations and came to the concluded that bureaucracy was an organization that rested on rational legal principles and maximized technical efficiency. After globalization, the level of corruption may be increased. The issues to get a proper solution go to administrative way or the judicial way to attain it and solve it. It should be a proper implementation process to the needy not for the exploiter

\section{REFERENCE}

1. https://www.business.com/articles/management-theory-ofmax-weber/

2. Mohid.et.al (2015) "Good Governance and Organization Performance in Public Sector"

3. International journal administration and governance pp 63-68

4. Weber, Marianne, Max Weber: A Biography. New Brunswick

5. Philip Gorski / David Trubek (eds.), Max Weber's Economy and Society: A Critical Companion. Stanford: UP 2005, pp. 164-182.

6. https://owiki.org/wiki/Organizational_behavior

7. https://www.coursehero.com/file/67235621/Unit-6Discussion-2docx/

\section{AUTHORS PROFILE}

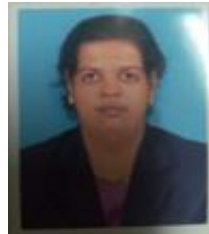

I am Dr .Shyamala Diwakaran, $\mathrm{Ph} . \mathrm{D}$ in Management Studies, my ug is B.Sc Visual Communication and M.Sc and MBA\{HR $\}$ are distance education,this is my research work based education and experience 14years of e-governance experience donea research on lack of Implementation process especially in local governance leads to organized exploitationPros and cons of unapproved building 2007 to 2010.My petition has a importantfactor for the law( un approved building) all over the nation based on that I have done a research in India .Lack of implementation process especially in local governance leads to organized exploitation [petition 2015-2019] It is a conceptual research . It is your wish, I don't want suppress the facts. This is my humble request

1. "Stress and Management from working Women perspective". A literature Review International conference on contemporary issues in business 2014, pg.220-222.

2. "Later working hours, A Study on stress of working women in ITES Trichy and Chennai", Global Journal. For Research Analysis. volume 3, issue-11, 2014, pg.4-6. ISSN No. 2277-8160 (UGC listed publications).

3. "A Study on organizational stress in ITES employees working in MNC companies of Tamil Nadu", International Journal of Management (IJM), volume 8, issue 5, 2017. pg.no. 93-100. ISSN No. 0976-6502. (Thomson Reuters).

4. I Converted my thesis into my Book (ISBN 978-613-9-99818-0) in Lambert Academic Publishing ) https://www.amazon.ca/StressManagement-Among-ITES-Employee/dp/6139998182

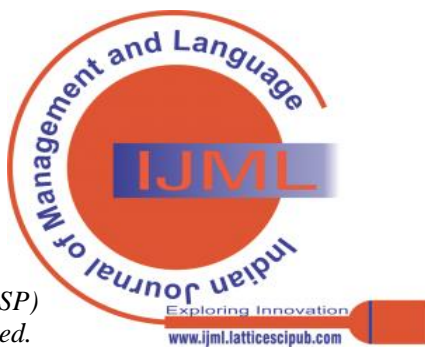

